\title{
Cinismo e Parresía: Um Paralelo entre Foucault e Montaigne
}

\author{
[Cynicism and Parresía: A Parallel between Foucault and Montaigne]
}

\section{Bruno Alonso®}

Resumo: O período final do trabalho de Foucault no Collège de France pode ser interpretado, em parte, como resultado de uma intensa influência de Pierre Hadot no desenvolvimento do seu pensamento e por ser uma tentativa de reconquistar a sabedoria perdida dos filósofos helenistas e romanos. Ambos consideram Montaigne como um dos pioneiros, talvez o único filósofo moderno que tenha compreendido a extrema relevância dessa questão. Os Ensaios criam uma base histórica concreta, pois estabelecem um diálogo íntimo com a tradição helenística e romana, produzindo assim algo único no contexto da literatura renascentista. O plano desta apresentação é explorar mais especificamente o cinismo e um dos princípios fundamentais dessa escola, a noção de parresía (fala franca), em uma tentativa de compreender como o modelo de vida cínico foi assimilado por Foucault e Montaigne. Ao se dedicar à temática do cuidado de si, Foucault revela seu desencanto com o obscurantismo da filosofia cristã e com a cegueira deixada como herança pelo mecanicismo da filosofia cartesiana. A maneira de reverter isso seria olhar para o passado e Montaigne seria o caminho certo a ser percorrido. Palavras-chave: Foucault, Montaigne, ética, cinismo, cuidado de si.

\begin{abstract}
The final period of Foucault's work in the Collège de France can be interpreted, in part, as the result of an intense influence of Pierre Hadot in the development of his thought and as an attempt to regain the lost wisdom of the Hellenist and Roman philosophers. Both consider Montaigne as one of the pioneers, perhaps the only modern philosopher who has understood the extreme relevance of this question. The Essays create a concrete historical basis, for they establish an intimate dialogue with the Hellenistic and Roman tradition, thus producing something unique in the context of Renaissance literature. The plan of this essay is to explore more specifically cynicism and one of the fundamental principles of this school, the notion of parresia (frank speak), in an attempt to understand how the cynical example of life was assimilated by Foucault and Montaigne. By focusing on the subject of care of the self, Foucault reveals his disenchantment with the obscurantism of Christian philosophy and with the blindness inherited from the mechanicism of Cartesian philosophy. The way to reverse this would be to look back and Montaigne would be the right way to go.
\end{abstract}

Keywords: Foucault, Montaigne, Ethics, cynicism, care of the self.

\footnotetext{
${ }^{\star}$ Doutorando em História da Filosofia pelo Programa de Pós-Graduação em Filosofia da Universidade Federal do Rio de Janeiro (PPGF). E-mail: brunoalonso@id.uff.br. ORCID: https://orcid.org/0000-0003-0534-2950.
} 
O início desta apresentação será dedicado a uma análise detalhada sobre o cinismo, da sua origem histórica e dos principais representantes dessa corrente filosófica do helenismo. Nossa referência fundamental é Diógenes Laércio, cuja obra riquíssima de anedotas, repletas de humor e narrativas inusitadas sobre as vidas dos filósofos antigos, possibilitará uma compreensão profunda sobre o verdadeiro sentido da filosofia cínica. Foucault recebe o cinismo como uma referência inigualável, a única filosofia que consolidou com perfeição o exemplo de como viver sob uma relação íntegra e direta com a verdade. Sua abordagem explora o caráter político do cinismo, em uma tentativa de retratar o cínico como o homem da parresía, o filósofo que enfrenta a conjuntura política com uma coragem avassaladora, sem preocupar-se com as retaliações e as consequências trágicas que lhe ameaçam. Em Montaigne o cinismo se insere dentro de uma perspectiva antropológica, pois o cinismo é repensado em uma correlação com o estilo de vida dos povos ameríndios do novo mundo. $\mathrm{O}$ enaltecimento da natureza e o desprezo pelas convenções humanas, é o fundamento teórico do cinismo que Montaigne recebe e toma para si como um princípio filosófico vital. Mas o que há de semelhante entre Foucault e Montaigne? A suposição que tentaremos sustentar é que a noção de parresía e a sua respectiva raiz cínica se faz presente no pensamento de ambos filósofos. Foucault, em Le courage de la vérité, se predispõe a descobrir quais são os meios práticos e atitudes que conduzem a uma forma de vida totalmente subordinada ao comprometimento com a verdade. Em Montaigne encontramos exatamente isso, um exemplo preciso de como pôr em prática a parresía, que é algo que se reflete nas entrelinhas do texto dos Ensaios, uma franqueza que atua como critério ético que norteia os rumos do seu pensamento. Foucault enxerga em Montaigne uma referência única na modernidade, o filósofo renascentista que realizou o nobre feito de reconquistar a essência perdida da filosofia helenística e romana, que fez renascer para a posteridade uma concepção pragmática da filosofia, voltada a uma ética e a uma estética da existência.

Em comparação com as demais escolas filosóficas do período helenístico, o cinismo talvez tenha sido a única filosofia não doutrinária! A imagem construída do

${ }^{1}$ Podemos mencionar alguns fatores que motivaram até certo ponto a marginalização do cinismo. Primeiro, em 
pensador cínico é a de um homem completamente desprendido das coisas exteriores, vive perambulando pelas ruas, não possui posses e se contenta com o pouco que lhe é oferecido. Antístenes foi o pioneiro. Mas Diógenes é a figura central que encarnou com maior plenitude a essência do modo de vida cínico? ${ }^{2}$, O exemplo do rato que anda sem rumo, sem nada temer nem nada desejar, arrebatou Diógenes que enxergou nisso uma valiosa lição de vida. Diógenes não morava em lugar algum pois sua casa é o cosmos?. Sem pátria, cidadão do mundo, fazia tudo em praça pública, até mesmo as suas necessidades mais íntimas. Praticava exercícios, se colocava em situações extremas, como uma estratégia para se manter preparado para todas as adversidades do destino. Por isso deitava na areia quente para enfrentar o sol do verão e abraçava estátuas con- geladas no inverno. O que mostra claramente a preocupação dos cínicos com a parte física. Exercícios mentais por si só não bastam, é necessário colocar o corpo à prova, como uma forma de áskesis (exercício)

A filosofia cínica faz uma oposição radical entre aquilo que é natural (physis) e o que é convenção (nomos). O governo, as leis, a cultura e a arte: o cínico ignora todos esses artifícios. Esse foi o ponto de cisão entre estoicos e cínicos, pois no estoicismo o poder de organização coletiva do homem passou a ser visto como algo natural que reflete a harmonia do cosmos. Esse radicalismo cínico fez dessa filosofia um movimento revolucionário, pois desde o início suas ideias floresceram no interior de Atenas, porém jamais sendo submissa à organização política dominante. Impossível não lembrar da clássica anedota, que

\footnotetext{
razão do próprio estilo de vida pregado pelos seus cofundadores, o desprezo pelas instituições e consequentemente a falta de compromisso com o estabelecimento de uma escola como parte da sociedade na qual viviam. Em segundo lugar, pela maneira como essa tradição foi recebida pelos filósofos que lhes sucederam, uma vez que o cinismo foi injustamente menosprezado e relegado a uma posição inferior das outras escolas.

2 “(...) certa vez Diôgenes, vendo um rato correr de um lado para outro, sem destino, sem procurar um lugar para dormir, sem medo das trevas e não querendo nada do que se considera desejável, descobriu um remédio para as suas dificuldades. (...) servia-se indiferentemente de qualquer lugar para satisfazer qualquer necessidade, para o desjejum ou para dormir, ou conversar; (...) no verão ele rolava sobre a areia quente, enquanto no inverno abraçava estátuas cobertas de neve, querendo por todos os meios acostumar-se às dificuldades" (Diógenes Laêrtios, Livro VI, 22-23).

3 "Perguntaram-lhe o que ganhava com a filosofia, e a resposta foi: 'No mínimo, estar preparado para enfrentar todas as vicissitudes da sorte'. Interrogado sobre sua pátria, respondeu: 'Sou um cidadão do mundo'”' (Ibidem, 63).

4 "Diôgenes dizia que há dois tipos de exercício: o espiritual e o físico. Na prática constante do exercício físico formam-se percepções que tornam mais expedita a prática da excelência. O exercício físico e o espiritual se integram e se completam. As condições físicas satisfatórias e o vigor são elementos fundamentais para a saúde da alma e do corpo" (Ibidem, 70).

5 "Enquanto em certa ocasião o filósofo tomava sol no Cranêion, Alexandre, o Grande, chegou, pôs-se à sua frente e falou: 'Pede-me o que quiseres'! Diógenes respondeu: 'Deixa-me o meu sol'”' (Ibidem, 38).
} 
põe frente a frente, o imperador macedônio e Diógenes o cínico $5^{5}$. O cinismo surgiu na Antiguidade tardia em uma época em que havia um enorme desencanto com a política, a democracia não mais existia e boa parte do mundo conhecido já tinha sido dominado pelo império de Alexandre.

Antístenes aprendeu a arte sofística com Górgias, um dos sofistas mais influentes da Atenas clássica 6. Sócrates foi seu mestre e a figura principal que direcionou os primeiros rumos do que viria a ser o cinismo. Sócrates é visto como o pai não somente dos cínicos mas de todas as seitas filosóficas que se desenvolveram na época helenística. Vemos então uma mistura de retórica sofística com ascetismo socrático enquanto parte da formação intelectual daquele que veio a ser o precursor dos cínicos. Dois dados históricos imprescindíveis para a compreensão da origem dessa escola 7 . É curioso notar que desde muito cedo o cinismo gerou consequên- cias que foram muito além das suas ambições 8 . O estoicismo durante muito tempo foi a filosofia predominante no seio do Império Romano desfrutando de um prestígio incomensurável em meio a cultura, a literatura e a polítca romana. Como poderia o cinismo ter gerado uma filosofia como essa e se tornado guia para senadores e imperadores do maior império do Ocidente? É impressionante constatar o alcance do estoicismo dentro do sistema político da Roma antiga e reconhecer que essa filosofia só veio a existir graças aos ensinamentos de Crates, um pensador cínico sem muita expressão e pouco reconhecido.

Em Le courage de la vérité, último curso, ministrado em 1984, poucos meses antes de falecer, Foucault elabora uma análise ampla sobre o conceito de parresía - "fala franca" ou "dizer verdadeiro" - e desenvolve um estudo a partir das primeiras fontes que remontam à Platão e aos cínicos. Denomina seu objeto de es-

\footnotetext{
${ }^{6}$ Um dos diálogos platônicos leva o nome do sofista Górgias. Ao lado de Protágoras (que também figura em um diálogo de Platão), podemos considerá-los como alguns dos sofistas mais proeminentes da Atenas clássica. Platão alimentou uma forte polêmica contra os sofistas. Acusava-os de mercenários por cobrarem caro por suas aulas e de charlatães por sustentarem a crença de que um homem bem treinado na arte da retórica é capaz de discursar sobre qualquer coisa.

7 “Inicialmente Antístenes foi ouvinte do retor Górgias, exibindo por isso o estilo retórico em seus diálogos. (...) Antistenes andava diariamente quarenta estádios para ouvir Sócrates. De Sócrates ele aprendeu a resistência e emulou-lhe a impassibilidade, dando início assim à filosofia cínica" (Diógenes Laêrtios, Livro VI, 1-2).

8 "Parece ainda que lhe podem ser atribuídas as origens do estoicismo mais viril. (...) Antístenes antecipou a impassibilidade de Diógenes, a moderação de Crates, a firmeza de Zênon, e estabeleceu os fundamentos da doutrina" (Ibidem, 14-15).

${ }^{9}$ Foucault introduz a palavra "aleturgia" nas aulas de 23 e 30 de janeiro, ministradas no Collège de France, no ano de 1980. Essa palavra resulta de uma derivação do termo grego alethourgés que significa basicamente o ato
} 
tudo como aleturgia, que pode ser definida como as formas de produção da verdade 9 . Para Foucault, os cínicos incorporam o preceito de vida não dissimulada de uma forma incomparável. Esta é a essência da parresia, a absoluta liberdade de ser verdadeiro consigo mesmo e com os outros, mesmo que isso represente enfrentar as ameaças daqueles que lhe cercam. O parresiasta se atém em obedecer à verdade, ser honesto com seus próprios pensamentos e revelar a verdade para o seu interlocutor, mesmo que isso signifique se expor ao risco de ser mal recebido ou até mesmo arriscar sua própria vida. A parresía se opõe, portanto, à retórica. O retórico, ao contrário, direciona seu discurso para produzir um efeito no seu interlocutor, previamente articulado, cujo conteúdo não possui comprometimento com a verdade.

O cinismo me parece portanto uma forma de filosofia na qual modo de vida e dizer-a-verdade estão direta, imediatamente, ligados um ao outro. Como isso se manifesta? Estou falando por ora apenas do cinismo em sua forma antiga, como pode ser ates- tado nos textos do período helenístico e romano, isto é, [em] Diógenes Laércio, [em] Dion Crisóstomo, até certo ponto [em] Epicteto, e também naqueles textos satíricos ou críticos escritos por Luciano no fim do século II ou pelo imperador Juliano em sua polêmica com os cínicos. Através desses textos, podemos ver que o cínico é constantemente caracterizado como o homem da parresía, o homem do dizer-a-verdade. Claro, o termo parresía não é reservado aos cínicos, não os designa constante e exclusivamente. Ele é encontrado designando outras formas de fala franca filosófica, de palavra livre e verídica. Lembremse por exemplo da maneira como Arriano, prefaciando as Conversações de Epicteto, diz que vai ser possível, lendo essas conversações, compreender o que é o pensamento e a parresía de Epicteto, isto é, o que ele pensava e a maneira como o exprimia livremente 10 . 
Foucault considera a parresía como algo intrínseco e indissociável ao modo de vida cínico. A liberdade e o desprendimento do filósofo cínico lhe dão o poder de se expressar sem o menor pudor ou constrangimento. Mas o termo parresía, conforme atesta Foucault, não foi usado única e exclusivamente pelos cínicos, aparecendo, por exemplo, no prefácio das Diatribes, escrito por Arriano. Ele também se refere ao capítulo vinte e dois das Diatribes, passagem em que Epicteto tece alguns elogios à filosofia cínica. Epicteto define o cínico como katdskopos, ou seja, uma espécie de batedor, no sentido militar do termo, que explora o território inimigo e depois retorna trazendo boas novas, pintando a imagem do cínico como o "cão" errante que não se encaixa em nenhum sistema político, mas que é o único capaz de anunciar a mais pura verdade isento do temor e do medo. Os estoicos, assim como Epicteto, possuem uma dívida histórica com os cínicos, que foram os filósofos responsáveis por estabelecer os alicerces que deram origem a sua doutrina, principalmente em relação ao ideal ascético de total indiferença pelos prazeres.

A análise histórica de Foucault sobre o conceito de parresía pode ser dividida em três categorias temáticas: enraizada na literatura da tragédia grega e no ideal político perseguido por Tucídides; uma segunda orientada pela perspectiva filosófica socrática e platônica; e, por último, o tema mais relevante para nossa discussão, o modo de vida cínico, enquanto o ápice do ensinamento de como viver como um legítimo parresiasta $^{11}$. Foucault identifica a presença do cinismo em diversos momentos históricos, indo desde o ascetismo cristão, passando pela arte moderna, até o anarquismo e outras manifestações contemporâneas. O cinismo foi, dessa forma, um fenômeno que extrapolou as suas raízes históricas e se tornou uma forma de pensamento autônoma, transhistórica, com uma existência que deixou uma marca definitiva na subjetividade do homem ocidental.

Foucault explica com precisão o alcance das práticas cínicas, pela

\footnotetext{
11 "En efecto, el estudio de este fenómeno, que advino a propósito del cuidado de sí a primera vista con prioridad de lo éticoantropológico, revela en sus apariciones una filiación directa con el ámbito de lo político, que llevará en el curso de 1984 a establecer tres modalidades parresiásticas clásicas, una de carácter político que se ligará con la figura de Pericles bosquejada por Tucídides, pero ilustrada profusamente por la tragedia, otra de carácter filosófico vinculada con el ámbito socrático y una terceira asociada con el escándalo que ejemplifican los exponentes del cinismo" (MARSICO, Claudia. La noción de parrhesía em M. Foucault a la luz de los estúdios sobre las filosofias del círculo socrático, 2017, pp. 49-50). A mística em torno do cinismo e o espanto provocado pelo radicalismo dessa filosofia deram a Foucault uma visão absolutamente pragmática da parresia, que não era simplesmente um ideal teórico-discursivo, mas um fundamento ético vital para o modo de vida cínico.
} 
coragem de enfrentar situações extremas, que aos olhos do senso comum seriam encaradas como uma lástima impossível de ser suportada. $\mathrm{O}$ ato de pobreza voluntária dos filósofos cínicos nos inspira uma profunda perplexidade. Não se trata de uma aceitação da pobreza por circunstâncias contingentes ou por imposição do destino: "É uma pobreza inquieta, uma pobreza insatisfeita consigo mesma, que sempre se esforça por alcançar novos limites, até atingir o chão do absolutamente indispensável" 12, Os cínicos escolhem deliberadamente se colocar nessa condição, desprezando o dinheiro e todos os bens materiais ${ }^{13}$. Essa condição de extrema pobreza exigia também a aceitação da escravidão, cuja consequência era viver no limite da sobrevivência, em um estado de mendicância. Tão surpreendente é o fato desses filósofos enfrentarem tais desafios de forma positiva e conseguirem ser indiferentes ao sofrimento: “(...) a pobreza cínica afrontava algo que era mais grave ainda que a escravidão e que a mendicidade. Ela afrontava a adoxía" 14. A simplicidade dos cínicos é autêntica, ardorosa no desprezo pela glória (adoxía), iam ao encontro dos maiores infortúnios, porque queriam acima de tudo serem senhores de si mesmos. Desejar a fama é se entregar a outrem, submeter-se ao julgamento volátil de uma multidão indiscernível, que em última instância revela uma debilidade ulterior ao homem, um desejo mórbido que afasta o filósofo da busca pela excelência.

Só o que é da ordem da natureza é que pode ser um princípio de conformidade para definir a vida reta de acordo com os cínicos. Nenhuma convenção, nenhuma prescrição humana pode ser aceita na vida cínica, se não for exatamente conforme ao que se encontra na natureza, e somente na natureza. É assim, claro, que os cínicos recusam o casamento, recusam a família, praticam, ou pretendem praticar, a união livre. Assim,

\footnotetext{
12 FOUCAULT, Michel. A coragem da verdade, 2017, p. 227-228.

13 “O próprio Antístenes recebeu o nome de 'cão puro e simples', e foi o primeiro, como diz Dioclés, a dobrar o manto e a vestir somente essa roupa, e usar um bastão e uma sacola” (Diógenes Laêrtios, Livro VI, 13). Antístenes adotou um modo de vida de austeridade, usava um único manto como vestimenta, um bastão rudimentar para auxiliá-lo nas caminhadas e uma sacola para guardar apenas o necessário. O rigor ascético dos cínicos influenciou profundamente algumas ordens monásticas cristãs medievais, como, por exemplo, os franciscanos, que faziam voto de pobreza e levavam uma vida completamente desprendida de posses e riquezas.

${ }^{14}$ FOUCAULT, Michel. A coragem da verdade, 2017, p. 229.
} 
os cínicos recusam todos

os tabus e as convenções alimentares 15 .

A recusa pelas convenções e pelos artifícios das leis humanas é uma atitude que os cínicos levavam até as últimas consequências ${ }^{16}$. Nesse sentido, é importante constatar que a parresía precisa ser compreendida para além do aspecto meramente discursivo, possuindo um valor orgânico e substancial para o modo de vida cínico. A submissão irrestrita à natureza é o horizonte que guia a conduta dos cínicos, que enxergavam as imposições morais como artimanhas, normas cujo objetivo consiste em reprimir e aprisionar os impulsos mais elementares do homem. Costumes básicos da sociedade como o casamento e o modelo de família tradicional foram renegados por Diógenes de Sínope ${ }^{17}$. Os cínicos não eram nem um pouco requintados no que diz respeito às práticas alimentares, ao ponto de provocarem uma enorme polêmica pela aceitação da antropofagia ${ }^{18}$. Tais práticas foram associadas ao estilo de vida dos ameríndios brasileiros, como veremos mais adiante ao tratar sobre Montaigne.

O ensaio de Montaigne no qual a presença da filosofia cínica aparece de forma mais impactante é o capitulo Des cannibales (I, 31). Texto que aborda um suposto relato de um europeu que visitou terras brasileiras e manteve um contato direto com a população nativa. O estilo de vida desses povos afetou drasticamente a concepção europeia sobre a natureza humana e mostrou como a civilização poderia seguir em uma outra direção, de uma maior harmonia e identificação com a natureza 19 . Assim como os cíni$\cos$ que acreditavam que as leis

\footnotetext{
15 Ibidem, p. 232.

16 “Certa vez Diógenes viu um menino bebendo água com as mãos em conchas e jogou fora o copo que tirara da sacola dizendo: 'Um menino me deu uma lição de simplicidade'. Ele jogou fora também sua bacia ao ver um menino que quebrara o prato comer lentilhas com a parte côncava de um pedaço de pão" (Diógenes Laêrtios, Livro VI, 37).

17 "Diógenes ridicularizava a nobreza de nascimento, a fama e similares, chamando-as de ornamento ostentatório do vício. A única organização política correta, dizia ele, é a universal. Defendia a comunidade das mulheres, e não reconhecia outro casamento além da união do homem que persuade com a mulher que se deixa persuadir. Consequentemente, os filhos devem ser também comuns" (Ibidem, 72).

18 "Diógenes nada via de estranho em roubar qualquer coisa de um templo ou em comer a carne de qualquer animal, nem via qualquer impiedade em comer a carne humana” (Diógenes Laêrtios, Livro VI, 73).

${ }^{19}$ No Renascimento podemos observar um retorno ao ideal helenístico que compreendia a virtude como uma atitude de submissão do homem à grandeza da natureza: "Frente a uma natureza incompreensível e imprevisível, Montaigne não se posicionará como mestre ou possuidor, mas muito mais como protegido de reverência para com a Mãe Natureza; ele procura mais a consonância com ela do que seu conhecimento. O Renascimento retoma o saber antigo que prescreve subordinação à medida natural: a natureza é onde se cruzam liberdade e necessidade; e a perfeição da personalidade, ideal helenístico e renascentista da sabedoria, é a realização da ligação íntima e primordial entre homem e natureza" (AZAR, Celso. Acerca do naturalismo de Montaigne, 1994, p. 30).
} 
e as convenções criadas pelo homem são, na realidade, subterfúgios que prejudicam a vida em comunidade e impedem a vivência da verdadeira virtude, os índios trouxeram um exemplo nítido de como o modo de vida cínico pode ser posto em prática. Ao entrar em contato com esses povos, os europeus descobriram uma realidade inteiramente nova, pequenas tribos que viviam em equilíbrio com a natureza, sem leis formais, poligâmicas e que possuíam o costume de praticar a antropofagia 20 . O choque provocado pela descoberta do novo mundo fez com que os europeus duvidassem das suas crenças, principalmente da crença no ideal de que há uma natureza humana única. A própria concepção da natureza humana com base nos preceitos cristãos de superioridade da condição humana sobre os outros animais passou a ser questionada. Portanto, não seria nenhum absurdo afir- mar que a idealização do mito do bom selvagem, impulsionada pela descoberta dos povos ameríndios, se fortaleceu ainda mais pela influência da filosofia cínica ${ }^{21}$.

[B] A natureza cria sempre leis melhores do que as nossas. Atestam-no a idade de ouro de que falam os poetas e o estado natural em que vemos viverem os povos que não conhecem leis artificiais 22 ,

No ensaio De l'experience (III, 13) Montaigne fala como um exímio cínico e defende a ideia de que as leis humanas, sem exceção, são equívocas e injustas. Critica a justiça francesa e aponta para a artificialidade das leis que mais complicam do que resolvem os problemas da sociedade. A complexidade da estrutura do modelo de Estado europeu leva a um abismo

\footnotetext{
${ }^{20}$ Montaigne critica o consenso comum dos seus contemporâneos, de menosprezar os povos recém descobertos e tratá-los como bárbaros por praticarem a antropofagia. Argumenta que em meio a guerra religiosa entre católicos e protestantes ocorreram diversos atos hediondos, muitos mais cruéis e violentos do que aqueles imputados aos ameríndios: "Não me parece excessivo julgar bárbaros tais atos de crueldade, mas que o fato de condenar tais defeitos não nos leve à cegueira acerca dos nossos. Estimo que é mais bárbaro comer um homem vivo do que o comer depois de morto; e é pior esquartejar um homem entre suplícios e tormentos e o queimar os poucos, ou entregá-lo a cães e porcos, a pretexto de devoção e fé, como não somente o lemos mas vimos ocorrer entre vizinhos nossos conterrâneos; e isso em verdade é bem mais grave do que assar e comer um homem previamente executado" (Michel de Montaigne. Essais, III, 13, 1066B).

21 “Montaigne afirmará, en 'De los caníbales' (I, xxxi) y en 'De los carruajes' (III, vi), sus dos ensayos más influyentes en la conformación del mito del buen salvaje, que los excesos de la civilización debilitan la salud física y moral de los hombres. En 'De los caníbales', los europeos serán vistos como frutos cultivados 'que hemos alterado con nuestras artes, desviándolos del orden común', con el objetivo de adaptarlas 'al placer de nuestro gusto corrompido.' (I, xxxi, t. I, p. 268); y en 'De los coches', se presentará el contacto entre el mundo indígena y la degradada civilización europea como un 'contagio'” (CASTANY, Bernat. Perros en el paraíso: la influencia de la filosofia cínica en la construcción del mito del buen salvaje, 2015, p. 232).

22 Michel de Montaigne. Essais, III, 13, 1066B.
} 
de formalismo e mediocridade. Vejam a simplicidade na qual viviam o homem na idade do ouro e os povos do novo mundo, diz Montaigne, exemplos que escancaram a fragilidade da nossa sociedade. Será que somos realmente tão bons como pensamos ou apenas não conseguimos enxergar nossos próprios defeitos? Não estaríamos distorcendo a realidade para tolamente convencernos de uma falsa superioridade? São questões deixadas por Montaigne que desafiaram a mentalidade colonialista do homem europeu e permaneceram como um desafio para os pretensos conquistadores.

A presença da influência cínica nos Ensaios tem um sentido amplo e não se reduz apenas à analogia com os ameríndios brasileiros. Montaigne menciona Diógenes de Sínope em diversos ensaios e encontra nele o genuíno arquétipo do modo de vida cínico. A parresía cínica - como vemos também na interpretação de Foucault - não possui uma conotação estritamente verbal. A postura, as atitudes e o simples olhar para o mundo, já carregam consigo traços importantes que conferem a espontaneidade representativa da parresid ${ }^{23}$, Montaigne via nos cínicos um inestimável exemplo de como enfrentar a vida com moderação, um espelho para a verdadeira virtude, pelo desprezo pelos prazeres e o desapego pelos bens mundanos e materiais.

Os princípios socráticos tornaram-se a chave do modo de vida cínico. Estes princípios formaram também a base para o estoicismo. O ideal de ascensão à apatheia e à autarkeia surge a partir da figura de Sócrates, a principal personagem, responsável por deixar um importante legado para as escolas helenísticas como um todo. A apatheia, entendida como o estado de espírito de total insensibilidade de ânimo, e a autarkeia, que pode ser definida como a capacidade de governar a si mesmo. O propósito final dos cínicos e das demais escolas helenísticas é alcançar a ataraxia, isto é, o estado de imperturbabilidade da alma. Se os deleites e sofrimentos nascem do julgamento, consciente e interior, que fazemos sobre nossas representações, é missão da filosofia exercitar o espírito e aprimorálo na eterna luta contra as ilusões do mundo exterior. Diógenes de Sínope viveu em uma plenitude infinitamente maior do que o im-

\footnotetext{
23 “[C] Diógenes, masturbando-se em público, lamentava perante a turba de que não pudesse dar gozo ao ventre, em o roçando. A quem lhe perguntava por que comia na rua e não buscava lugar mais apropriado, respondia: 'é porque tenho fome na rua'. Hipárquia só foi admitida na companhia de Crátes sob a condição de seguir em tudo os usos e costumes da seita" (Ibidem, II, 12, 585C).
} 
perador Alexandre, mais livre e poderoso, pois sua eudaimonia (felicidade) dependia única e exclusivamente de si mesmo 24 ,

A leitura de Foucault sobre a filosofia antiga possui nuances que lhe afastam da maneira como Hadot compreende essa tradição. Hadot argumenta que Foucault não leva em consideração um aspecto primordial: o propósito espiritual de se elevar à universalidade. Hadot leva a discussão para uma outra direção e enxerga na filosofia antiga um objetivo de superação da individualidade, em nome de uma realidade superior. Os exercícios espirituais são um caminho para libertar o "eu" e despertar a consciência para um sentimento de pertencimento à comunidade humana e cósmica. A crítica de Hadot à abordagem de Foucault sobre a filosofia antiga, se dirige principalmente ao desenvolvimento de uma preocupação excessiva com a relação do indivíduo consigo mesmo ${ }^{25}$. Foucault teria, então, agido tendenciosamente na abordagem da te- mática da cultura de si, ao estabelecer que a constituição de uma identidade individual é a finalidade da prática filosófica. A concepção de que há uma razão universal que rege o cosmos, e que o homem é um microcosmo inserido dentro de um macrocosmo, é um preceito fundamental para as escolas filosóficas da Antiguidade. Hadot argumenta que Foucault se deixou levar por uma tendência característica da filosofia moderna, de subestimar o aspecto místico e esotérico da filosofia antiga. Para Foucault as práticas de si devem ser produzidas e pensadas no âmbito das relações sociais, como uma afirmação soberana do indivíduo, livre de uma perspectiva transcendental ${ }^{26}$, Em relação ao cinismo, em particular, é justamente no desprezo pelas convenções e na exaltação da natureza onde reside o único meio efetivo de aspirar à universalidade. Questão essa que Foucault leva em consideração ao investigar o cinismo, em Le courage de la vérité, mas sem explorar o cosmopolitismo e o na-

\footnotetext{
24 “[A] Diógenes, em seu tonel, divertindo-se em seus botões em zombar das vaidades humanas, escarnecendo de Alexandre, encarando os homens como moscas ou bexigas cheias de vento" (Michel de Montaigne. Essais, I, 50, 303-304A).

25 “(...) a descrição que M. Foucault realiza do que eu havia denominado 'exercícios espirituais', e que ele prefere chamar de 'técnicas de si', está demasiadamente centrada sobre o 'si' ou, ao menos, sobre certa concepção do eu” (HADOT, Pierre. Exercícios espirituais e filosofia antiga, 2014, p. 292).

26 "Compreendo bem o motivo pelo qual Foucault obliterou esses aspectos, que ele conhecia bem. Sua descrição das práticas de si (como, aliás, minha descrição dos exercícios espirituais) não é somente um estudo histórico, mas pretende implicitamente oferecer ao homem contemporâneo um modelo de vida (que Foucault chama de 'estética da existência'). Ora, segundo uma tendência quase geral do pensamento moderno, tendência talvez mais instintiva do que refletida, as noções de 'Razão universal' e de 'natureza universal' agora não têm mais muito sentido. Era então útil colocá-las entre parênteses” (HADOT, Pierre. Exercícios espirituais e filosofia antiga, 2014, 293).
} 
turalismo dos cínicos como elementos cruciais para a compreensão da relevância política da prática da parresía.

Conforme revela Hadot em $O$ que é a filosofia antiga?, a relação de Montaigne com a filosofia helenística não é um fato corriqueiro e de pouca importância:

No Renascimento assistirse-á a uma renovação não somente das tendências doutrinais, mas das atitudes concretas da filosofia antiga: o epicurismo, o estoicismo, o platonismo, o ceticismo. Nos Ensaios de Montaigne, por exemplo, vê-se o filósofo procurar praticar os diferentes modos de vida propostos pela filosofia antiga: "Meu ofício, minha arte, é viver" - Seu itinerário espiritual vai assim levá-lo do estoicismo de Sêneca ao probabilismo e Plutarco, passando pelo ceticismo, para terminar final e definitivamente no epicurismo ${ }^{27}$.

Desde o início até o fim da composição dos Ensaios o helenismo foi uma valiosa fonte de inspi- ração. Pierre Villey foi o autor responsável por introduzir a teoria de que a trajetória intelectual de Montaigne teve três grandes momentos. Um período inicial de dois anos que ficou conhecido como uma fase estoica, uma fase intermediária cética denominada como o momento da crise pirrônica, e, por fim, um período de maior proximidade com a filosofia epicurista que durou até o final da sua vida. Embora essa identificação com cada uma das escolas não seja absoluta, ainda assim permite assinalar características predominantes nas diferentes fases da vida do autor ${ }^{28}$, Montaigne constrói diálogos constantes com os antigos. Sêneca e Plutarco, por exemplo, estavam entre seus autores prediletos. Esse cuidado especial com os helenistas e romanos tinha um sentido histórico bem determinado, uma vez que Montaigne viveu em um momento em que a filosofia escolástica ainda desfrutava de um enorme prestígio. É o que caracteriza o Renascimento enquanto um movimento histórico de transformação em relação ao mundo medieval: um movimento de ruptura com a filosofia cristã amplamente arraigada nos preceitos da filosofia aristotélica. Montaigne parece querer se

\footnotetext{
27 Idem. O que é a filosofia antigua?, 2014, p. 369.

28 Cf. VILLEY, Pierre. Les essais de Montaigne, 1932.
} 
distanciar da teologia cristã e trilhar um novo rumo, enxergando a vida com a mesma vivacidade de um filósofo pagão, escrevendo como um legítimo poeta, um texto literário, sem a mínima ambição de chegar a alguma verdade absoluta.

Montaigne pinta a si mesmo na sua obra, expõe seus pensamentos ao exame crítico, sem nenhum tipo de fingimento ou dissimulação. No prefácio Au lecteur observamos claramente a proposta dos Ensaios: uma espécie de autorretrato, uma pintura de si mesmo, retrato fiel e sem fingimento que revela todos os defeitos, vícios e traços da personalidade do seu autor 29 , A escrita é então um exercício de preparação para a morte e os Ensaios são o espelho de um filósofo que buscou de todas as formas desafiar o grande enigma que é a morte. Ao expor seus temores e revelar até mesmo seus pensamentos mais profundos, Montaigne busca ao longo da sua obra lançar um olhar minucioso sobre suas ideias, de modo que o exercí- cio da parresía possui um propósito essencialmente pragmático, no sentido do aperfeiçoamento ético e intelectual.

A visão da filosofia como um contínuo exercício de aprimoramento ético do indivíduo tem uma significância excepcional para os filósofos helenistas e romanos. Depois das conquistas de Alexandre, o império foi divido de tal forma que os cidadãos não podiam participar das decisões políticas na pólis. Esse sentimento de impotência e desencanto com a política instaurou um ambiente novo, muito distinto do sistema democrático ateniense que condenou Sócrates à morte. Platão criticou severamente a democracia e idealizou um novo modelo de Estado no diálogo A República, mas compreendia os valores éticos individuais como interdependentes do sistema político dominante. Esse movimento de emancipação do indivíduo que ocorre no contexto da filosofia helenística foi um dos fatores que atraiu e fascinou Montaigne e Foucault.

\footnotetext{
29 “[A] Eis aqui, leitor, um livro de boa-fé. Adverte-o ele de início que só o escrevi para mim mesmo, e alguns íntimos, sem me preocupar com o interesse que poderia ter para ti, nem pensar na posteridade. Tão ambiciosos objetivos estão acima de minhas forças. Voltei-o em particular a meus parentes e amigos e isso a fim de que, quando eu não for mais deste mundo (o que em breve acontecerá), possam nele encontrar alguns traços de meu caráter e de minhas ideias e assim conservem mais inteiro e vivo o conhecimento que de mim tiveram. Se houvesse almejado os favores do mundo, ter-me-ia enfeitado e me apresentaria sob uma forma mais cuidada, de modo a produzir melhor efeito. Prefiro, porém, que me vejam na minha simplicidade natural, sem artifício de nenhuma espécie, porquanto é a mim mesmo que pinto. Vivos se exibirão meus defeitos e todos me verão na minha ingenuidade física e moral, pelo menos enquanto permitir a conveniência. Se tivesse nascido entre essa gente de quem se diz viver ainda na doce liberdade das primitivas leis da natureza, asseguro-te que de bom grado me pintaria por inteiro e nu. Assim, leitor, sou eu mesmo a matéria deste livro, o que será talvez razão suficiente para que não empregues teus lazeres em assunto tão fútil e de tão mínima importância" (Michel de Montaigne. Essais, Au Lecteur, 3A).
} 
problema principal não está mais no clássico "conhece a ti mesmo" de Sócrates. Fundamental é não apenas conhecer a si mesmo, mas transformar a si mesmo30. A filosofia para os pensadores helenistas e romanos consistia em práticas diárias e constantes de exercícios espirituais. De nada vale idealizar uma série de teorias mirabolantes se esse conhecimento não proporciona um efeito estritamente prático para a vida do filósofo 31 .

(...) o tema do retorno a si foi sem dúvida, a partir do século XVI, um tema recorrente na cultura "moderna". Porém, penso também que não podemos deixar de nos aperceber que este tema, no fundo, foi reconstituído por fragmentos, por migalhas - em sucessivas ten- tativas que jamais se organizaram de modo tão global e contínuo quanto na Antiguidade helenística e romana. O tema do retorno a si nunca foi dominante entre nós como na época helenística e romana. Por certo, encontramos no século XVI toda uma ética e estética de si que é, aliás, muito explicitamente referida à que encontramos nos autores gregos e latinos dos quais lhes falo. Penso que seria necessário reler Montaigne nesta perspectiva, como uma tentativa de reconstituir uma estética e uma ética do eu 32 .

A linguagem cômica e espontânea dos Ensaios guarda uma profunda semelhança com a ideia foucaultiana de uma parresía cí-

\footnotetext{
30 "In ancient schools of thought philosophy was considered to be a way of life, a quest for wisdom, a way of being and ultimately a way of transforming the self. Spiritual exercises were a form of pedagogy designed to teach their practitioners the philosophical life that had both a moral and existential value. These exercises wereaimed at nothing less than a transformation of one's world view and personality by involving all aspects of one's being, including intellect, imagination, sensibility and will. In the contemporary world, schools have frequently being seen as an appropriate location for the moral education of young people. Socrates provided a set of dialogical spiritual exercises that epitomised the injunction 'know yourself!' and provided a model for a relationship of the self to itself that constituted the basis of all spiritual exercise that is at the very centre of a total transformation of one's being (see Davidson 1997). In this model, the process of dealing with a problem takes primacy over the solution (Hadot 1987). Foucault suggested re-instating care of the self, the maxim that 'know yourself' supplanted. This provides schools with an ancient philosophical basis or model, at once transformative, ethical, dialogic and pedagogical, which could both complement and correct certain emphases in Foucault's later thinking about truth, subjectivity and care of the self" (BESLEY, Tina. Foucault, truth telling and Technologies of the self in schools, 2005, p; 87).

31 "Não se faz mais então a teoria da lógica, isto é, do falar bem e do pensar bem, mas pensa-se e fala-se bem; não se faz mais a teoria do mundo físico, mas contempla-se o cosmos; não se faz mais a teoria da ação moral, mas age-se de uma maneira reta e justa" (HADOT, Pierre. Exercícios espirituais e filosofia antiga, 2014, p. 264).

32 FOUCAULT, Michel. Hermenêutica do Sujeito, 2006, p. 305.
} 
nica. Foucault propõe uma leitura inovadora sobre Montaigne e enxerga nele o iniciador da retomada de um período áureo da filosofia, em que eram valorizados a bios, o cuidado de si, uma ética e uma estética da existência. O nome de Montaigne é mencionado por Foucault numa pequena parte de uma das aulas ministradas em 1982, que compõem a obra L'Herméneutique du sujet. Foucault aponta Montaigne como o pensador moderno que foi responsável por resgatar os valores ancestrais que se perderam durante os longos séculos de cristi- anismo. O filósofo renascentista resgatou o brilho da Antiguidade, trouxe de volta o espírito prático dos romanos e a sofisticação teórica dos gregos. Nos Ensaios encontramos a ideia de uma prática de si, uma preocupação com a natureza individual e vemos claramente o retorno ao cuidado com o corpo, outro tema obscuro, abandonado e omitido pela cristandade. Foucault recebe Montaigne como uma peça chave para os rumos da história da filosofia, o autor pioneiro, na era moderna, a conseguir recuperar a aura da filosofia helenística e romana.

\section{Referências}

AZAR, Celso. Acerca do naturalismo de Montaigne. PUC-Rio: Revista O que nos faz pensar, pp 28-38, Vol. 6, No 8, 1994.

CASTANY, Bernat. Perros en el paraíso: la influencia de la filosofia cínica en la construcción del mito del buen salvaje. Universidad de Barcelona: Anales de Liter ${ }^{\circ}$ atura Hispanoamericana, Vol. 44, pp. 221-251, 2015.

BESLEY, Tina. Foucault, truth telling and Technologies of the self in schools. Journal of Educational Enquiry, Vol. 6, № 1, 2005.

CARNEIRO, Alexandre. Exercícios espirituais e parrhesia nos Ensaios de Montaigne. Curitiba: Rev. Filos. Aurora, Vol. 23, No 32, p. 113129, 2011.

CLÉMENT, Michelet. Le Cynisme à la Renaissance: D'Erasme à Montaigne. Librairie Droz: Geneva, 2005.

DIÓGENES LAÊRTIOS. Vidas e doutrinas dos filósofos ilustres. Tradução de Mário da Gama Kury. 2a edição. Brasília: Editora Universidade de Brasília, 2008.

FOUCAULT, Michel. A hermenêutica do sujeito. Traduzido por Márcio Alves e Salma Tannus. São Paulo: Editora Martins Fontes, 2006. 
A coragem da verdade. Tradução de Eduardo Brandão. São Paulo: Editora Martins Fontes, 2017.

FUIOREA, Mihai. Michel Foucault and the Concept of Parrhesia. Annals of the University of Bucharest Philosophy Series, Vol. LXIII, No 2, pp. 95-110, 2014.

GOULET-CAZE, Marie Odile. L'ascèse cynique: un commentaire de Diogène Laërce. Paris: Vrin, 1986.

GROS, Frédéric. Foucault: a coragem da verdade. Tradução de Marcos Marcionilo. São Paulo: Parábola Editorial, 2004.

HADOT, Pierre. Exercícios espirituais e filosofia antiga. Tradução de Flavio Loque e Loraine Oliveira: $1^{a}$ edição, São Paulo: É Realizações Editora, 2014.

. O que é a filosofia antigua? Tradução de Dion Macedo. São Paulo: Edições Loyola, 2014.

MARSICO, Claudia. La noción de parrhesía em M. Foucault a la luz de los estúdios sobre las filosofias del círculo socrático. João Pessoa: Auklärung, Vol. 4, No 3, pp. 47-60, 2017.

MONTAIGNE, Michel de. Ensaios. Tradução de Sérgio Milliet. Porto Alegre: Editora Globo S.A., 1972.

PEARSON, Joseph. Michel Foucault Fearless Speech. Los Angeles: Semiotext(e), 2001.

ROJAS, Maria. Michel Foucault: la 'parrêsia', une éthique de la vérité. Université Paris-Est, 2012.

VILLEY, Pierre. Les essais de Montaigne. Paris: Editions Edgard Malfère, 1932.

Recebido: $19 / 02 / 2019$

Aprovado: 21/04/2019

Publicado: 13/05/2019 